\title{
Experimental investigation on the mechanical behaviour of the fiber reinforced high-performance concrete tunnel segment
}

\author{
Yining Ding a ${ }^{\text {a }}$ Hekai Liu ${ }^{\mathrm{a}, *}$, Fernando Pacheco-Torgal ${ }^{\mathrm{b}}$, Said Jalali ${ }^{\mathrm{b}}$ \\ a State Key Laboratory of Coastal and Offshore Engineering, Dalian University of Technology, 116024 Dalian, China \\ ${ }^{\mathrm{b}}$ Research Unit C-TAC (Sustainable Construction Branch), University of Minho, 4800-058 Guimarães, Portugal
}

\section{A R T I C L E I N F O}

\section{Article history:}

Available online 25 October 2010

\section{Keywords:}

Composite effect

Mechanical behaviour

Tunnel segment

FRHPC

Symmetric-inclination beam

\begin{abstract}
A B S T R A C T
The main objective of this paper is to investigate the composite effect of macro steel fiber and steel rebar on the mechanical behaviour of tunnel segment with fiber reinforced high-performance concrete (FRHPC). A new experimental method is used for simulating the loading state of the tunnel segment. The experiment including several symmetric-inclination beams with various steel ratios and fiber contents has been carried out. The results indicate that the addition of $50 \mathrm{~kg} / \mathrm{m}^{3}$ steel fibers can partly replace the shear reinforcement, and increases the ultimate load and the energy absorption capacity as well as the toughness. The combination of steel fibers and steel rebars illustrates synergistic response and indicates an optimal choice of reinforcement for tunnel segment.
\end{abstract}

(c) 2010 Elsevier Ltd. All rights reserved.

\section{Introduction}

The shield tunnel technology is widely used in tunnel construction in soft soil condition, and most of them adopt conventional steel reinforced concrete $(\mathrm{RC})$ tunnel segments. Due to the brittle characteristics and low tensile strength of concrete, traditional RC tunnel segments are prone to crack or damaged during production, transportation, installation and service periods. The safety, the permeability, the serviceability and the durability of the tunnel are strongly influenced by such macro cracks.

The relevant literatures [1-7] describe numerous studies on the fiber reinforced concrete. A common conclusion is that the addition of fibers to the concrete enhances the mechanical behaviour of RC members and it leads to a change in failure mode from a brittle shear failure into a pseudo-ductile failure or even a ductile flexural failure. Steel fibers could be advantageous for the partial or total replacement of stirrups [8]. However, due to the lack of design rules for steel fiber reinforced concrete (SFRC) tunnel segment, engineers have usually designed SFRC tunnel segments by adopting the same rules that valid for conventional RC segments [9]. The investigation of SFRC tunnel segment is far behind the construction and structure demands, while the manufacture of the tunnel segment for lab investigation is difficult and expensive. The method using simply supported beam with exerting axial force by jack at each ends (Fig. 1) [10] is usually adopted for lab investigation to simulate the stress state of tunnel segment, while some problems exist in this method: (1) the axial force exerted by jack

\footnotetext{
* Corresponding author. Tel.: +86 41184709756; fax: +86 41184674141.

E-mail address: dlookd@hotmail.com (H. Liu).
}

offers a constant axial force and cannot reflect the real loading condition of tunnel segment because the normal stress of the tunnel section varies with the vertical rock pressure in the practice; (2) the segments with different central angle and curvature cannot be simulated by simply supported beam.

In order to avoid the unreasonable problems above mentioned, a new test method by name of symmetric-inclination beam (Fig. 2) [10-12] is used to investigate the load-carrying capacity and the toughness of tunnel segment. The method is reasonable and the major advantages are as follows:

- Compared with conventional method using simply supported beam with constant axial force $\left(N_{\mathrm{c}}\right)$ (Fig. 1), an inclined support reaction $(R)$ is introduced including axial component $(N)$ (Fig. 2), which increased proportionally with the vertical load.

- Different angle of support reaction with axial component $(N)$ can simulate the segments of different central angle and curvature. The inclination $(\theta)$ of symmetric-inclination beam is between 0 and $90^{\circ}$. When $\theta$ is equal to $90^{\circ}$, the beam becomes conventional simply supported beam.

- The decrease of $\theta$ will enhance the axial component $(N=V \times$ $\cot \theta)$, thus result in the increase of the negative moment induced by axial force component $\left(M_{n}=V \times \cot \theta \times e_{0}\right)$. The negative moment can reduce the moment induced by the vertical load $\left(M_{\mathrm{a}}=V \times a\right)$, so the flexural behaviour will be improved with the decrease of $\theta$ (see Figs. 2 and 3). In this program, a constant inclination of $45^{\circ}$ is chosen to investigate the mechanical behaviour of symmetric-inclination beam. The beam with $45^{\circ}$ inclination of support reaction can simulate the segment with $90^{\circ}$ central angle (see Fig. 4). 


\section{Nomenclature}

$M_{\mathrm{n}} \quad$ negative moment induced by axial force

$e_{0} \quad$ vertical distance from support to neutral axis

$M_{\mathrm{a}} \quad$ moment induced by apply load

$\varphi 6.5 @ 80$ diameter of the stirrups $=6.5 \mathrm{~mm}$, stirrup spacing = $80 \mathrm{~mm}$

$\varphi 6.5 @ 150$ diameter of the stirrups=6.5 mm, stirrup spacing = $150 \mathrm{~mm}$

N0-80 stirrup spacing $=80 \mathrm{~mm}$, stirrup ratio $\rho_{\mathrm{v}}=0.55 \%$, without steel fibers

SF25-80 stirrup spacing $=80 \mathrm{~mm}$, stirrup ratio $\rho_{\mathrm{v}}=0.55 \%$, fiber dosage of $25 \mathrm{~kg} / \mathrm{m}^{3}$
SF50-0 beam with $50 \mathrm{~kg} / \mathrm{m}^{3}$ steel fibers, but without stirrups

$\varepsilon_{80} \quad$ tensile strain of longitudinal reinforcement at $80 \mathrm{kN}$

$\varepsilon_{120}$ tensile strain of longitudinal reinforcement at $120 \mathrm{kN}$

$\varepsilon_{u} \quad$ tensile strain of longitudinal reinforcement at ultimate load

$D_{c} \quad$ energy absorption by concrete before cracking,

$D_{8}^{f}=D_{8}-D_{\mathrm{c}}$ energy absorption up to a deflection $\delta_{8}$

$D_{12}^{f}=D_{12}-D_{c}$ energy absorption capacity up to a deflection $\delta_{12}$
- The formwork of symmetric-inclination beam is easy to fabricate and cost saving for lab investigation.

In this study, the combined action of macro steel fiber and steel rebar on the load-strain relationship of longitudinal rebars, loaddeflection relationship, ultimate load and energy absorption capacity of the SFRC tunnel segment are investigated by means of the symmetric-inclination beam test. Compared with conventional reinforced concrete, a safe and economic composite material should be found and applied to the underground construction.

\section{Experimental investigation}

\subsection{Materials}

The grade of the plain concrete was designed for C60 (Compressive strength of $60 \mathrm{MPa}$ ) and the mixture proportions are provided in Table 1 . The concrete was made with P. $\| 52.5 \mathrm{R}$ Portland cement and first class fly ash. The water to binder ratio was 0.33 . The coarse aggregates were crushed gravel with a maximum size of $10 \mathrm{~mm}$, and the fine aggregates were natural river sand.

Macro hooked end steel fibers (Fig. 5) with different fiber contents and conventional steel rebars (Fig. 6) with various reinforcement ratios had been used in this study.

- Macro steel fiber (RC-65/35-BN) (Fiber length $l_{\mathrm{f}}=35 \mathrm{~mm}$, equivalent diameter $d_{\mathrm{f}}=0.55 \mathrm{~mm}$, aspect ratio $\left.\lambda\left(l_{\mathrm{f}} / d_{\mathrm{f}}\right)=65\right)$, ca. 15,000 pieces $/ \mathrm{kg}$, tensile strength was of approximately $1345 \mathrm{MPa}$. The designed fiber contents were $0 \mathrm{~kg} / \mathrm{m}^{3}, 25 \mathrm{~kg} /$ $\mathrm{m}^{3}$ and $50 \mathrm{~kg} / \mathrm{m}^{3}$.

- The nominal diameter of the flexural reinforcement for all beams was $14 \mathrm{~mm}$ and the diameter of the stirrups was

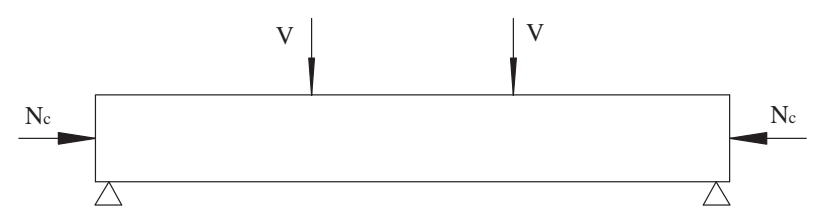

Fig. 1. Traditional methods.

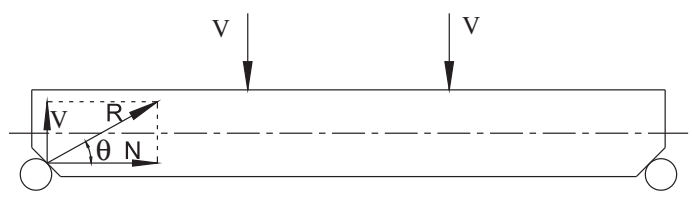

Fig. 2. Symmetric-inclination beam.
$6.5 \mathrm{~mm}$. The longitudinal rebars and stirrups had a yield stress of $490 \mathrm{~N} / \mathrm{mm}^{2}$ and $282 \mathrm{~N} / \mathrm{mm}^{2}$, an ultimate stress of 692 $\mathrm{N} / \mathrm{mm}^{2}$ and $439 \mathrm{~N} / \mathrm{mm}^{2}$, respectively, which were in accordance with Chinese Code for design of concrete structures [13].

\subsection{Experimental program}

The details of the specimens are listed in Table 2. Two fiber contents and two stirrup ratios were selected for investigating the composite effect of macro steel fiber and steel rebar on the mechanical behaviour of tunnel segment. The first stirrup spacing was $150 \mathrm{~mm}$ (the stirrup ratio $\rho_{\mathrm{v}}=0.3 \%$ ), and the second stirrup spacing was $80 \mathrm{~mm}$ (the stirrup ratio $\rho_{\mathrm{v}}=0.55 \%$ ). The variables of this experiment were fiber content and stirrup spacing. Other parameters, such as shear span to effective depth ratio $(a / d)$ and the longitudinal reinforcement ratio, were kept constant.

Each beam was designated by fiber content and stirrup spacing. $\mathrm{RC}$ beam is denoted as N0-80 (stirrup spacing $=80 \mathrm{~mm}$, stirrup ratio $\rho_{\mathrm{v}}=0.55 \%$, without fibers) and marked as the reference beam. The letters SF denote steel fiber reinforced beam; the first two

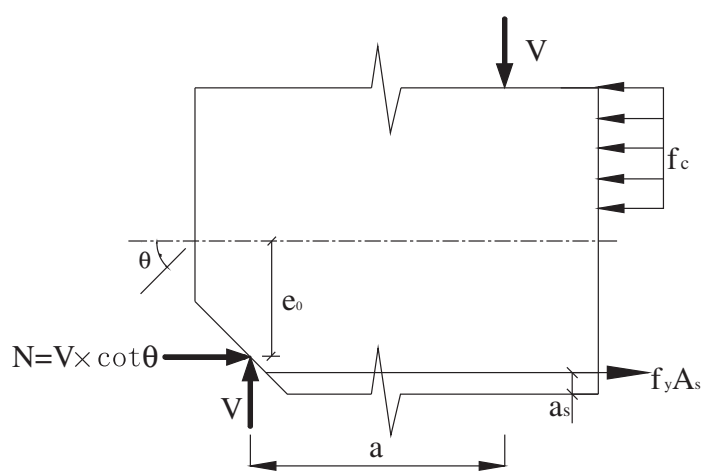

Fig. 3. Forces on portion of symmetric-inclination beam.

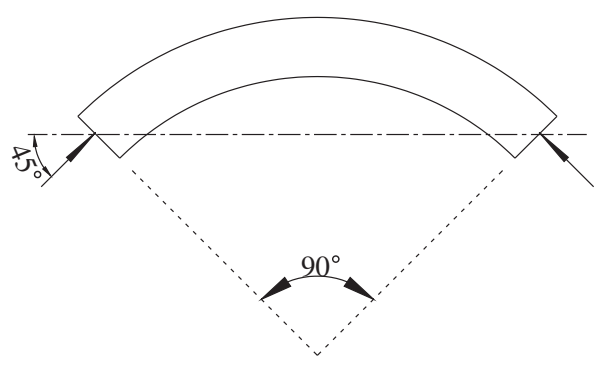

Fig. 4. Tunnel segment with $90^{\circ}$ central angle. 
Table 1

Mixture proportion of base matrix $\left(\mathrm{kg} / \mathrm{m}^{3}\right)$.

\begin{tabular}{|c|c|c|c|c|c|c|c|}
\hline Cement $(C)$ & Fly ash $(F A)$ & Binder $(B)$ & Sand $(0-5 \mathrm{~mm})$ & Coarse aggregate $(5-10 \mathrm{~mm})$ & Water $(W)$ & SP & Fiber content $\left(\mathrm{kg} / \mathrm{m}^{3}\right)$ \\
\hline 390 & $150(27.8 \%)$ & 440 & 808 & 808 & 178 & $9.72(1.8 \%)$ & 25,50 \\
\hline
\end{tabular}

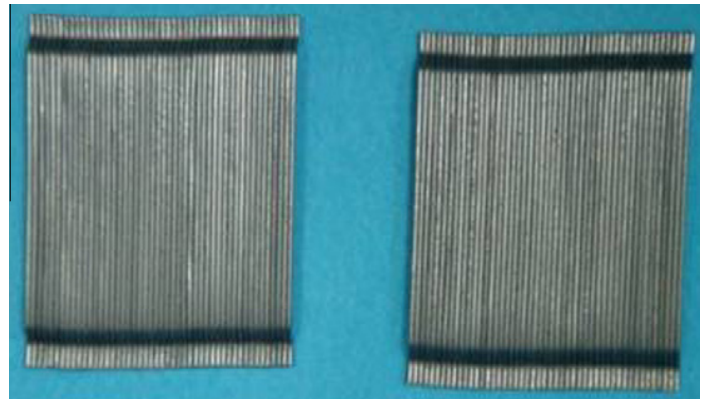

Fig. 5. Macro steel fibers.

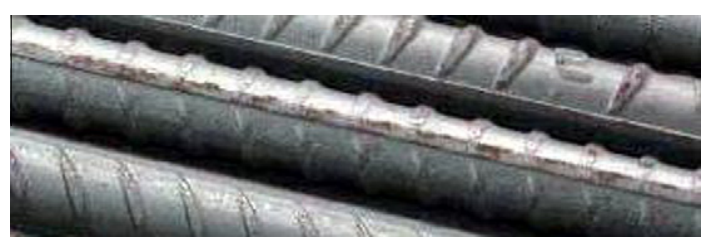

Fig. 6. Conventional steel rebars.

digits indicate fiber content and the following number indicates the spacing of stirrups. For example, SF25-80 refers to the beam with $25 \mathrm{~kg} / \mathrm{m}^{3}$ steel fiber and $80 \mathrm{~mm}$ stirrup spacing. The beam size was $\mathrm{B}($ width $) \times \mathrm{H}($ depth $) \times \mathrm{L}$ (length) $=150 \mathrm{~mm} \times 150 \mathrm{~mm} \times$ $1100 \mathrm{~mm}$, tested on a span $L_{\mathrm{sp}}=1050 \mathrm{~mm}$, and a $45^{\circ}$ inclination at both ends. The shear span length $L_{\mathrm{ssp}}$ was $350 \mathrm{~mm}$. The test was conducted in $10000 \mathrm{kN}$ hydraulic servo testing machine and the specimen was subjected to two equal concentrated loads. The beams for load-versus-displacement responses were deformation-controlled and tested when the specimens were 28 days old. The deformation rate of the test was $0.3 \mathrm{~mm} / \mathrm{min}$. A linear variable differential transformer (LVDT) was placed to measure the displacement at the mid-span. Strain gauges were glued to the main reinforcement at mid-span to measure the strain of longitudinal rebars under the influence of steel fibers (Fig. 7).

\section{Results and analysis}

\subsection{Compressive strength}

In order to investigate the compressive strength of fiber reinforced concrete, uniaxial compression test was carried out on cubic specimens, measuring $150 \times 150 \times 150 \mathrm{~mm}$, with a constant loading rate of $0.6 \mathrm{MPa} / \mathrm{s}$, after the curing phase according to Chinese guideline [14]. The mean values of compressive strength of all samples after 28 days are illustrated in Table 3. It can be seen that the addition of fibers has no significant influence on the compressive strength of hardened concrete. The addition of steel fibers aims in converting the properties of brittle concrete into a ductile material, generally improving the compressive ductility of concrete [15]. The compressive strength of all the samples exceeded $60 \mathrm{~N} /$ $\mathrm{mm}^{2}$ after 28 days. Therefore, the proposed mix design had produced the concrete that meets satisfactorily the strength requirement of HPC.

\subsection{Strain of mid-span longitudinal rebars}

Tensile strains in the longitudinal rebars at mid-span of the beams were measured. Fig. 8 shows the load-strain relationship of longitudinal reinforcement in the test beams, and compares the influence of steel fibers and stirrups on the strain of longitudinal reinforcement.

Table 2

Details of test beams.

\begin{tabular}{|c|c|c|c|c|c|}
\hline Beam number & Fiber dosage $\left(\mathrm{kg} / \mathrm{m}^{3}\right)$ & $a / d$ & Stirrup spacing $(\mathrm{mm})$ & Stirrup ratio (\%) & Longitudinal reinforcement ratio (\%) \\
\hline N0-80 & 0 & 3 & 80 & 0.55 & 2.6 \\
\hline SF25-80 & 25 & 3 & 80 & 0.55 & 2.6 \\
\hline SF25-150 & 25 & 3 & 150 & 0.3 & 2.6 \\
\hline SF50-150 & 50 & 3 & 150 & 0.3 & 2.6 \\
\hline SF50-0 & 50 & 3 & $\infty$ & 0 & 2.6 \\
\hline
\end{tabular}

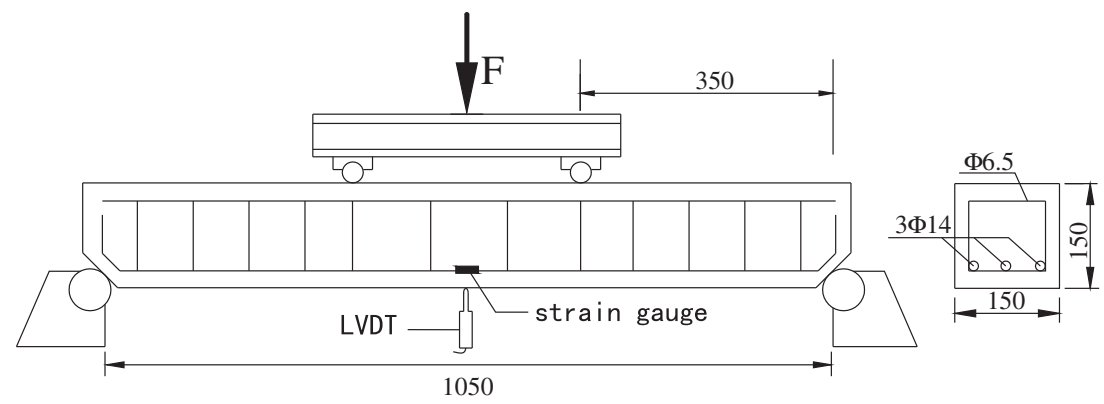

Fig. 7. Details of test setup (Unit: mm). 
Table 3

Comparison of compressive strength after 28 days.

\begin{tabular}{llll}
\hline & NC & SF25 & SF50 \\
\hline Compressive strength in 28 days $\left(\mathrm{N} / \mathrm{mm}^{2}\right)$ & 60.5 & 61 & 60 \\
\hline
\end{tabular}

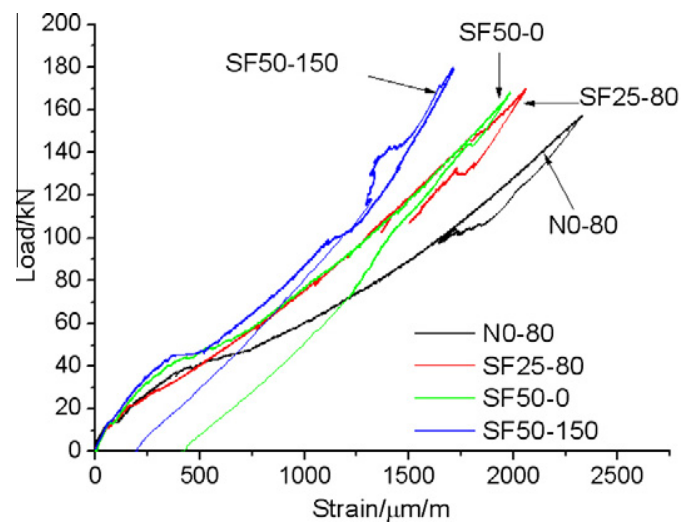

Fig. 8. Load-strain curves of longitudinal reinforcements.

From Fig. 8, it can be seen that the longitudinal reinforcement in all beams did not yield and the addition of steel fibers resulted in a clear reduction in the strain of longitudinal reinforcement.

The difference among these strains were only marginal in the initial loading stage, but with the formation and developing of flexural cracks, the steel fibers crossing the cracks could partially take up the tension released by concrete and restrict the development and the widening of the cracks. Compared to the beams with steel fibers, the strain in the longitudinal reinforcement of N0-80 was relatively large and achieved 2300 micro-strain at ultimate load. The variation of the longitudinal rebar strains of beam SF25-80 and SF50-0 were almost identical and lower than that of RC beam without fibers. One of the reasons could trace back to the fiber influence on reduction of the steel strain. For beam SF50-150 (stirrup spacing $=150 \mathrm{~mm}$, stirrup ratio $\rho_{\mathrm{v}}=0.3 \%$, fiber dosage of $50 \mathrm{~kg} /$ $\mathrm{m}^{3}$ ), the maximum strain reached only 1700 micro-strain, which was much less than those of other specimens. That pointed a possible positive composite effect of the combination from steel fiber and conventional stirrups on the strain of longitudinal steel rebars.

Table 4 shows the comparison of the corresponding strains in longitudinal steel of beam N0-80, SF25-80, SF50-0 and SF50-150, when the load reaches $80 \mathrm{kN}, 120 \mathrm{kN}$ and ultimate load. It can be seen that steel fibers contributed to reduce the strain of steel rebars as the steel fibers increase the tensile capacity of concrete and partially take up the tensile stress of the longitudinal reinforcement.

\subsection{Flexural shear performance}

The major failure patterns of all beams were caused by diagonal crack. The effect of fiber addition on the load-deflection curves for symmetric-inclination beams are presented in Figs. 9-11.

Table 4

Comparison of strains in longitudinal reinforcement at $80 \mathrm{kN}, 120 \mathrm{kN}$ and ultimate load.

\begin{tabular}{lrll}
\hline Beam number & \multicolumn{1}{c}{$\varepsilon_{80}$} & $\varepsilon_{120}$ & $\varepsilon_{\mathrm{u}}$ \\
\hline N0-80 & 1340 & 1898 & 2326 \\
SF25-80 & 1034 & 1507 & 2057 \\
SF50-150 & 926 & 1360 & 1711 \\
SF50-0 & 1060 & 1508 & 1985 \\
\hline
\end{tabular}

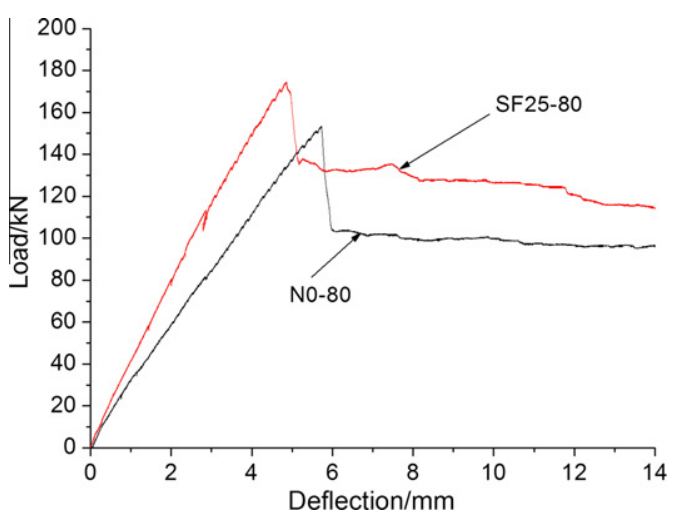

Fig. 9. Effect of steel fibers on the load-deflection curves.

Fig. 9 compares the load-deflection curves between the beams with constant stirrup spacing (stirrup spacing $=80 \mathrm{~mm}, \rho_{\mathrm{v}}=$ $0.55 \%$ ), but with different fiber contents ( 0 and $25 \mathrm{~kg} / \mathrm{m}^{3}$ ). Compared with the reference RC beam without fibers (N0-80), the addition of $25 \mathrm{~kg} / \mathrm{m}^{3}$ steel fibers enhanced not only the ultimate load and post-peak load-carrying ability, but also increased the energy absorption capacity over the entire deflection zone.

Fig. 10 shows the comparison of the load-deflection curves of the reference beam N0-80 (stirrup spacing $=80 \mathrm{~mm}, \rho_{\mathrm{v}}=0.55 \%$, without fibers) and the beams with reduced stirrup ratio $\left(\rho_{\mathrm{v}}=0.3 \%\right)$ and different fiber contents $\left(25 \mathrm{~kg} / \mathrm{m}^{3}\right.$ and $\left.50 \mathrm{~kg} / \mathrm{m}^{3}\right)$. Though the stirrup ratio $\rho_{\mathrm{v}}$ decreased $46.7 \%$, the ultimate load

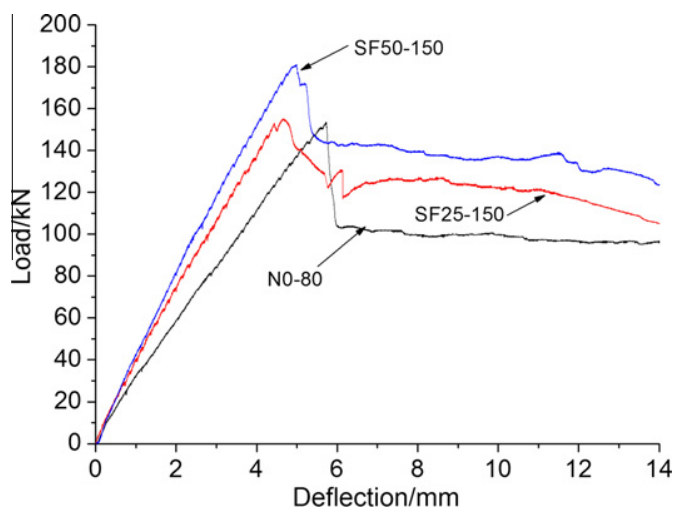

Fig. 10. Load-deflection of the beams with different fiber contents and reduced stirrup ratios.

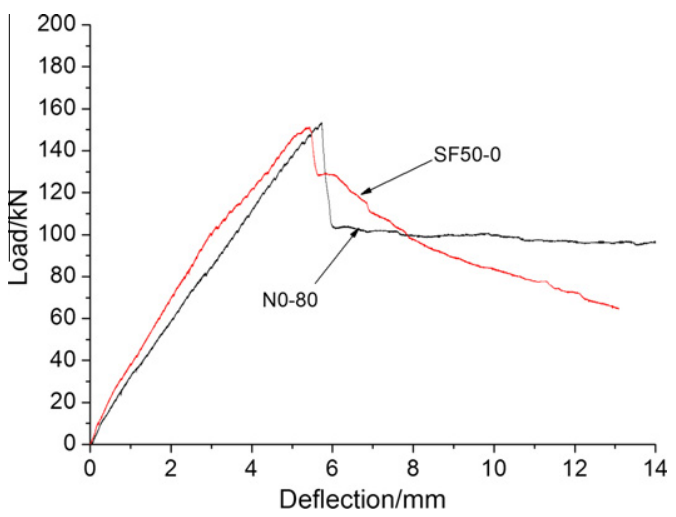

Fig. 11. Load-deflection of the beams with $50 \mathrm{~kg} / \mathrm{m}^{3}$ fibers and without stirrup 
Table 5

Test results of the cracking load, the ultimate load and the corresponding deflections.

\begin{tabular}{|c|c|c|c|c|c|}
\hline & \multicolumn{2}{|l|}{ Total applied load $F(\mathrm{kN})$} & \multirow{2}{*}{$\begin{array}{l}\text { Shear load } V=F / 2(\mathrm{kN}) \\
\text { Ultimate shear load }\left(V_{\mathrm{u}}\right)\end{array}$} & \multicolumn{2}{|c|}{ Corresponding deflection (mm) } \\
\hline & At first flexural crack $\left(F_{\mathrm{cr}}\right)$ & At failure $\left(F_{\mathrm{u}}\right)$ & & At first flexural crack $\left(\delta_{\mathrm{cr}}\right)$ & At failure $\left(\delta_{\mathrm{u}}\right)$ \\
\hline N0-80 & 10.9 & 153.4 & 76.7 & 0.30 & 5.7 \\
\hline SF25-80 & 11.1 & 176.1 & 88.1 & 0.24 & 4.8 \\
\hline SF25-150 & 12.6 & 156.2 & 78.1 & 0.25 & 4.7 \\
\hline SF50-150 & 12.4 & 180.3 & 90.1 & 0.21 & 4.9 \\
\hline SF50-0 & 12.6 & 150.9 & 75.5 & 0.20 & 5.4 \\
\hline
\end{tabular}

$\left(F_{\mathrm{u}}\right)$ of beams SF25-150 and SF50-150 increased with fiber contents. Also the stiffness and the energy absorption capacity of beams with steel fibers were enhanced due to the restricted cracking opening. The combined action of steel fibers and stirrups is obviously superior than the beam only reinforced with steel rebars.

Fig. 11 shows the comparison of the load-deflection curves of the reference beam N0-80 stirrup spacing $=80 \mathrm{~mm}, \rho_{\mathrm{v}}=0.55 \%$, without fibers) and the beam SF50-0 (without stirrups, but with $50 \mathrm{~kg} / \mathrm{m}^{3}$ steel fibers). Although the stirrups were totally replaced by $50 \mathrm{~kg} / \mathrm{m}^{3}$ steel fibers, the ultimate load capacity of beam SF50-0 only slightly decreased, however, the residual load-bearing capacity after the peak load and energy absorption capacity decreased rapidly compared to N0-80.

The flexural cracking load $\left(F_{\mathrm{cr}}\right)$, ultimate total applied load $\left(F_{\mathrm{u}}\right)$, ultimate shear load $\left(V_{\mathrm{u}}\right)$ and the corresponding deflection $\left(\delta_{\mathrm{cr}}, \delta_{\mathrm{u}}\right)$ of the beams with different stirrup ratios and fiber contents are summarised in Table 5.

From Table 5, it can be seen that the steel fibers significantly enhanced the ultimate shear load of the symmetric-inclination beams:

(1) When stirrup ratio maintained $0.55 \%$ (corresponding stirrup spacing of $80 \mathrm{~mm}$, see Table 2), compared with the reference beam without fibers (beam N0-80), the shear load $\left(V_{\mathrm{u}}\right)$ of the beam with $25 \mathrm{~kg} / \mathrm{m}^{3}$ steel fibers (beam SF25-80) increased $14.9 \%$.

(2) When stirrup ratio declined to $0.3 \%$ (the stirrup spacing increased from $80 \mathrm{~mm}$ to $150 \mathrm{~mm}$, see Table 2), compared with beam N0-80, the shear load $\left(V_{\mathrm{u}}\right)$ of the beam with $25 \mathrm{~kg} / \mathrm{m}^{3}$ and $50 \mathrm{~kg} / \mathrm{m}^{3} \mathrm{SF}$ (beam SF25-150 and SF50-150) increased $1.8 \%$ and $17.4 \%$, respectively.

(3) When stirrup ratio declined to $0 \%$ (without stirrups), compared with beam N0-80, the shear load $\left(V_{\mathrm{u}}\right)$ of the beam with $50 \mathrm{~kg} / \mathrm{m}^{3}$ (beam SF50-0) slightly decreased $1.6 \%$.

\subsection{Toughness}

In this study, the post-peak behaviour of RC beams in terms of toughness indexes is evaluated. According to RILEM recommendation [16] and German guideline [17], four toughness parameters
$\left(D_{8}^{f}, \quad D_{12}^{f}, f_{\text {eq. } 8}^{f}, f_{\text {eq.12 }}^{f}\right)$ are introduced to evaluate the energy absorption capacity and the residual load-bearing capacity of the specimens to a deflection $\delta_{8}=\delta_{\mathrm{cr}}+8$ or $\delta_{12}=\delta_{\mathrm{cr}}+12 \mathrm{~mm}$. The typical load-deflection curve is shown in Fig. 13. Similar to [16] and [17], $D_{8}, \mathrm{D}_{12}$ can be defined as the area under load-deflection curve, which is the total energy absorbed up to the certain deflection $\delta_{8}$ or $\delta_{12}$ of the specimen. $D_{8}$ or $D_{12}$ consists of two parts: the energy absorbed by plain concrete $D_{\mathrm{c}}$ and the energy absorbed of SFRC $D_{8}^{f}$ or $D_{12}^{f}$ (the shaded area in Fig. 12). The equivalent strength $f_{\text {eq. } 8}^{f}$ and $f_{\text {eq.12 }}^{f}$ can be determined by means of the following expressions:

$f_{\text {eq. } 8}^{f}=D_{8}^{f} L_{s s p} / 6 b h_{0}^{2}$

$f_{\text {eq.12 }}^{f}=D_{12}^{f} L_{s s p} / 10 b h_{0}^{2}$

The decreasing ratio of the equivalent strength $\Delta_{d}=\frac{\left(f_{\text {eq } 8}^{f}-f_{\text {eq.12 }}^{f}\right)}{f_{\text {eq. } 8}^{f}}$ is introduced for evaluation of the variation trend of the residual load-bearing capacity after peak load.

The calculated results of energy absorption and equivalent strengths of symmetric-inclination beams with different reinforcements are presented in Table 6 . It can be seen that the beam only

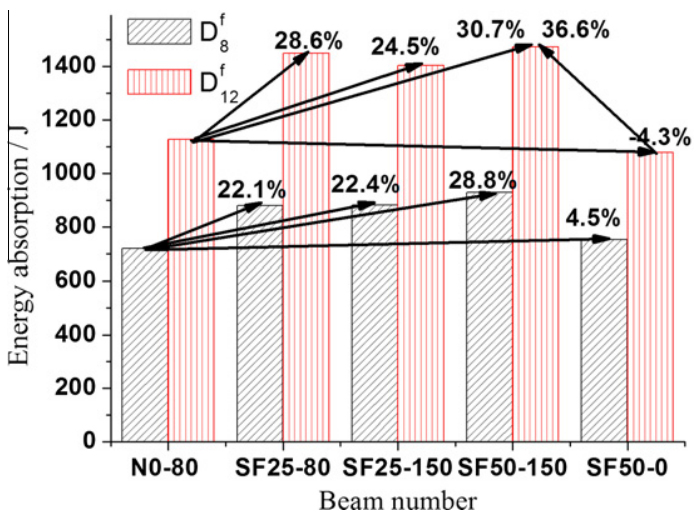

Fig. 13. Energy absorption and increment ratio of the toughness for beams with different reinforcements.

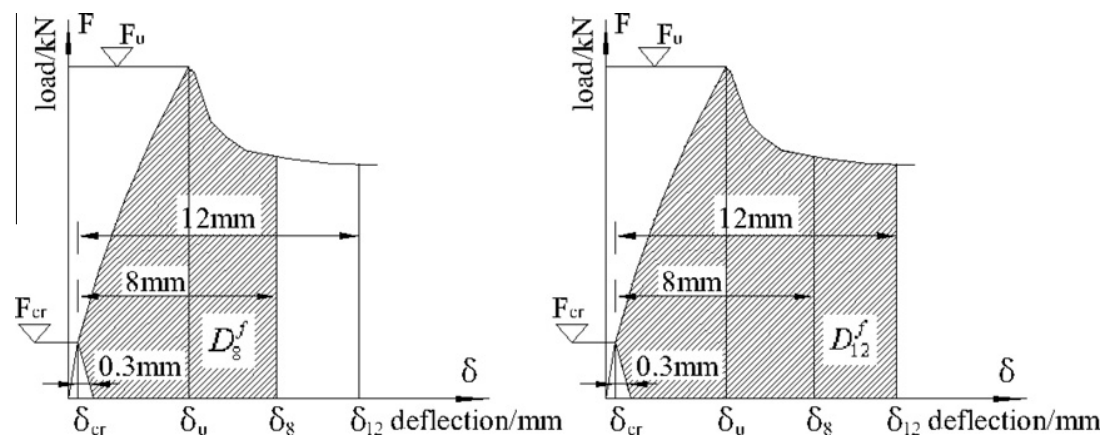

Fig. 12. Typical load-deflection curve and the calculation of energy absorption capacity. 
Table 6

Comparison of energy absorption and equivalent strength.

\begin{tabular}{|c|c|c|c|c|c|}
\hline & $D_{8}^{f}(\mathrm{kN} \mathrm{mm})$ & $D_{12}^{f}(\mathrm{kN} \mathrm{mm})$ & $f_{e q .8}^{f}\left(\mathrm{~N} / \mathrm{mm}^{2}\right)$ & $f_{\text {eq.12}}^{f}\left(\mathrm{~N} / \mathrm{mm}^{2}\right)$ & $\Delta_{d}(\%)$ \\
\hline N0-80 & 721.3 & 1127.1 & 20.1 & 18.9 & 6.2 \\
\hline SF25-80 & 881.0 & 1450.0 & 24.6 & 24.3 & 1.2 \\
\hline SF25-150 & 882.9 & 1403.4 & 24.7 & 23.5 & 4.6 \\
\hline SF50-150 & 929.1 & 1473.3 & 25.9 & 24.7 & 4.9 \\
\hline SF50-0 & 753.8 & 1078.2 & 21.1 & 18.1 & 14.2 \\
\hline
\end{tabular}

with stirrups (N0-80) and the beam only with steel fibers (SF50-0) showed relatively low toughness, especially at the large deflections of $\delta_{12}$. Therefore, beam N0-80 and SF50-0 are marked as the reference beam to quantify the hybrid effect of stirrups and steel fibers on toughness.

Fig. 13 shows the comparison of the energy absorption and the increment ratio of the toughness among the beams with various fiber contents and different stirrup ratios. The amounts of stirrups are converted into steel amount in $\mathrm{kg} / \mathrm{m}^{3}$, in order to compare the efficiency of the content of stirrups and fibers per kilogram intuitively. The conversion equation is proposed as follows:

$m_{s, \text { unit }}=m_{s} / b S h$

where $m_{s, \text { unit }}$ is the steel amount of stirrups in $\mathrm{kg} / \mathrm{m}^{3} ; m_{s}$ is the mass of a single-loop stirrups; $h$ is beam depth

The stirrup ratio of $0.3 \%$ is equivalent to a steel amount of $38.7 \mathrm{~kg} / \mathrm{m}^{3}$, and the stirrup ratio of $0.55 \%$ is equivalent to a steel amount of $71.9 \mathrm{~kg} / \mathrm{m}^{3}$.

It can be seen that:

- Compared to the reference beam N0-80, the addition of 25 $\mathrm{kg} / \mathrm{m}^{3}$ steel fibers enhanced the energy absorption $\left(D_{8}^{f}, D_{12}^{f}\right)$ of beam SF50-150 about $22.4 \%$ and $24.5 \%$, though the stirrup spacing increased from $80 \mathrm{~mm}$ to $150 \mathrm{~mm}$ (the stirrup ratio decreased about $46 \%$ ). It means that the $33.2 \mathrm{~kg} / \mathrm{m}^{3}$ of stirrups can be partially replaced by $25 \mathrm{~kg} / \mathrm{m}^{3}$ steel fibers, whereas the toughness of the member still increased.

- Compared to beam N0-80, the addition of $25 \mathrm{~kg} / \mathrm{m}^{3}$ steel fibers increased the energy absorption capacity $\left(D_{12}^{f}\right)$ of beam SF25-80 about $28.6 \%$. Similarly, the arrangement of $0.3 \%$ stirrups could enhance the energy absorption capacity $\left(D_{12}^{f}\right)$ of beam SF50150 about $36.6 \%$, compared to beam SF50-0. A significant positive synergistic effect on the post-peak properties, energy absorption ability as well as toughness can be achieved by the combination of steel fibers and steel rebars.

- Compared with beam N0-80, the energy absorption $D_{8}^{f}$ of beam SF50-0 increased $4.5 \%$, while the energy abortion at large deflection of $\delta_{12}$ decreased $4.3 \%$. Meanwhile, the value of $\Delta_{d}$ of beam SF50-0 is higher than that of the other beams from $130 \%$ to $1080 \%$. This means that the residual load-bearing capacity after peak load of SF50-0 dropped more rapidly than other beams, so the shear reinforcement ( $\varphi 6.5 @ 80)$ in this program cannot be totally replaced by only $50 \mathrm{~kg} / \mathrm{m}^{3}$ steel fibers.

\section{Conclusions}

In order to investigate the influence of the stirrups and steel fibers on the mechanical behaviour of tunnel segment/symmetric-inclination beam, a series of symmetric-inclination beams were tested. Based on the experimental result above mentioned, the following conclusions can be drawn:
1. The addition of steel fibers results in a clear decrease of the strain in longitudinal rebars for a given load.

2. The combined use of stirrups and steel fibers shows great synergetic effect on load-carrying capacity, energy absorption capacity as well as toughness of symmetric-inclination beam subjected to bending, shear and axial force.

3. The addition of $25 \mathrm{~kg} / \mathrm{m}^{3}$ fiber can partially reduce the amount of stirrups required (the stirrup ratio decreased about $46 \%$, the equivalent steel amount reduced $33.2 \mathrm{~kg} / \mathrm{m}^{3}$ ), namely enlarging the stirrup spacing from $80 \mathrm{~mm}$ to $150 \mathrm{~mm}$ in this study. A combination of fibers and stirrups can well satisfy load carrying ability and ductility requirements.

4. The addition of $25 \mathrm{~kg} / \mathrm{m}^{3}$ fibers can partly replace the conventional stirrups and enlarge the stirrup spacing from $80 \mathrm{~mm}$ to $150 \mathrm{~mm}$ (the equivalent steel amount reduced $33.2 \mathrm{~kg} / \mathrm{m}^{3}$ ).

5 . The arrangement of $0.55 \%$ stirrups (equivalent steel amount of $71.9 \mathrm{~kg} / \mathrm{m}^{3}$ ) can not be totally replaced by $50 \mathrm{~kg} / \mathrm{m}^{3}$ steel fibers.

\section{References}

[1] Noghabai K. Beams of fibrous concrete in shear and bending: the experiment and model. J Struct Eng 2000;126(2):243-51.

[2] Kwak Y-K, Eberhard MO, Kim W-S, Kim J. Shear strength of steel fiberreinforced concrete beams without stirrups. ACI Struct J 2002;99(4):530-8.

[3] Cucchiara C, Mendola LL, Papia M. Effectiveness of stirrups and steel fibers as shear reinforcement. Cem Concr Compos 2004;26:777-86.

[4] Ding Y, Zhang Y, Thomas A. The investigation on strength and flexural toughness of fiber cocktail reinforced self-compacting high performance concrete. Construct Build Mater 2009;23(1):448-52.

[5] Greenough T, Nehdi M. Shear behavior of fiber-reinforced self-consolidating concrete slender beams. ACI Mater J 2008;105(5):468-77.

[6] RILEM TC 162-TDF. Test and design methods for steel fiber reinforced concrete, $\sigma-\varepsilon$ design method, final recommendation, materials and structures, vol. 36(253); 2003. p. 560-7.

[7] Ding Y, You Z, Jalali S. Hybrid fiber influence on strength and toughness of RC beams. Compos Struct 2010;92(9):2083-9.

[8] Pascal C, Pierre R. Can steel fibers replace transverse reinforcements in reinforced concrete beams? ACI Mater J 1997;94(5):341-54.

[9] Sorelli L, Toutlemonde F. On the design of steel fiber reinforced concrete tunnel lining segments. In: 11th International conference on fracture; 2005.

[10] Olaf Hemmy. Zum Gebrauchs-und Tragverhalten von Tunnelschalen aus Stahlfaserbenton und stahfaserverstaerktem Stahlbeton, Technischen Universitaet Braunschweig; July 2003.

[11] Bernd F. Zum Einfluss verschiedener Stahlfasern auf das Verformungs-und Rissverhalten von Stahlfaserbeton unter den Belastungsbdingungen einer Tunnelschale, Mitteilung Nr. 95-8, RUHR-UNIVERSITAET BOCHUM INSTITUT FUER KONSTRUKTIVEN INGENIEURBAU; 1995.

[12] Maidl B. Stahlfaserbeton, Ernst \& Sohn Verlag fur Architektur und technische Wissenschaften, Berlin; 1991. ISBN: 3433011958.

[13] Code for design of concrete structures GB 50010-2002; 2002.

[14] China standardization association of engineering construction standard CECS 13-1989. Testing methods of steel fiber reinforced concrete; 1989.

[15] Ding Y, Kusterle W. Compressive stress-strain-relationship of steel fiber reinforced concrete at early age. Cem Concr Res 2000;30(10):1573-9.

[16] RILEM TC 162-TDF. Test and design methods for steel fiber reinforced concrete, bending test, final recommendation. Mater Struct 2002;35(253):579-82.

[17] DBV-Merkblaetter. Bemessungsgrundlagen fuer Stahlfaserbeton im Tunnelbau; 2002. 